\title{
Public Trust in Nigerian Police: A Test of Police Accessibility Effects
}

\author{
Adesina Shoyode $(\mathrm{PhD})$ \\ Arkansas Department of Correction, Wrightsville Unit, Arkansas USA. \\ E-mail: shoyodesina@gmail.com
}

Received: January 2, 2018 Accepted: February 24, 2018 Published: February 26, 2018

doi: 10.5296/jsss.v5i2.12721ＵRL: http://doi.org/10.5296/jsss.v5i2.12721

\begin{abstract}
Scholarly work on public trust in police has been an ongoing exercise for decades because the level of trust in the police can determine the way the public responds to and supports the police in the fight against crime and criminal, and ultimately can determine the effectiveness of the police organization. While studies in the developed world have examined various variables affecting public trust in police, none has examined police accessibility effects on public trust of the Nigerian Police. This study, therefore, examined police accessibility effect on public trust in the Nigerian Police. To carry out this objective, the study used data from the quality of democracy and governance in Nigeria by Afrobarometer, data Round 6, 2015-2016. Using descriptive statistics, correlation, and multiple regression analysis, the study found out that, reaching out to the Nigerian police to request assistance, report crime, volunteer information that may help in solving crime, and to be a witness is problematic, most especially for those in the low socio-economic status and consequently affect the public trust in Nigerian Police.
\end{abstract}

Keywords: Public Trust, Police Accessibility, Performance

\section{Introduction}

Scholarly work on how the public view the police has been an ongoing exercise for the past five decades (Brown \& Benedict, 2002). This is so because, the way the public conceptualizes and evaluates their police can determine the way they respond, the support they render, and the trust they have in the police (Wua, Poteyeva, \& Sun 2012). The effectiveness of police organization can be measured by the level of confidence and trust the public has in such police organization (Jackson et al., 2011). In other words, trust can be used to measure the success and effectiveness of the police and at the same time the success and effectiveness of the police can enhance public trust in the police (Goldsmith, 2005).

Hence throughout the world, particularly democratic societies, police organizations are 
becoming more concerned on how best to perform their duties in a professional manner and at the same time enhance the support and trust of the public. However, while the rest of the democratic societies are moving towards enhancing professionalism, legitimacy, and trust in the police, there is weak evidence to support the same in Nigeria (Out \& Aro, 2014) even after almost two decades of uninterrupted democracy. The Nigerian police still perform their functions with colonial mentality, by mere fiat, with brutality, and poor relationship with their community (Ojo, 2014). The assumption is, the means justify the end. In other words, it does not really matter how they (un)solved the crime or the means used in getting statements from their witnesses and suspects even if it means making them undergo undue punishments and inhumane conditions; and in some cases, using deadly force which may result in death (Igbo, 2017).

Not surprising, therefore, to see that the citizens, most especially those in the low social economic class (SES), are always in palpable fear anytime their paths cross with those of the law enforcement agencies, especially the Nigerian police, either as a witness or suspects. Thus, there is the ever-present fear of being accused of perpetrating the offence one reports to the police, reprisal attacks from the person the report is made against, due to the potential leakage of information by the police to the suspects. It is not uncommon for the police to require the person reporting a crime to fund the subsequent investigation and make endless return visits to the police station for one reason or the other, leading to an enormous loss of man-hours (Ladapo, 2011).

However, as strife as the relationship between the Nigerian police and the public is, the Nigerian Police Force (NPF) still aims to gain the support and trust of the public because it is obvious that the job of police has become increasingly complex and their role has expanded to incorporate new responsibilities; and the fight against crime and criminals can no longer be left in the hands of the law enforcement agents; they need the cooperation of the community they are established to protect if they want to deal effectively with crime, disorder, and other forms of emergency. And it is highly unlikely for the public to support or fully cooperate with a police organization it does not trust; making public a relevant issue in criminal justice at large and policing in particular. Surprisingly, as important as the issue of public trust in police is to policing, little attention has been given to it by police scholars in Nigeria; most of the research works on Nigerian police focus on the traditional challenges/obstacles facing the organization in terms of their deviance to rule of law and corrupt practices, (Akinlabi, 2017; Onyeozili, 2005), extra judiciary killing by the police (Ojedokun, 2014; Igbo, 2017), and community police (Ordu \& Nnam, 2017). Only few studies have examined public confidence or public perception of the Nigerian police (Ayodele \& Aderinto, 2014; John, 2017), and none has specifically examined how police accessibility affect public trust. Thus, this study aims to fill the lacuna of knowledge regarding public accessibility effects on public trust in Nigerian police by examining the role, if any, played by police accessibility on public trust.

\section{Theoretical Framework}

\subsection{Performance Theory}

The design of this paper is based on the assumptions that public trust in the police is based on the performance of the police; and how easily accessible the police are to the public prior, during, or after crime could impact the public trust in the police. Thus, this study utilizes 
performance theory as a guide. Performance theory posits that, trust and distrust in governments or institutions tightly linked to how good or bad such government or institution is doing, in other words, trust is an indicator of good performance (Bouckaert, Van de Walle, Maddens, \& Kampen, 2002). Put differently, the quality of services rendered by the government or institution determines the trust or distrust of the people in such government or institution; citizens will trust the government or institution with good performance and distrust the government or institution with bad performance.

The theory further states that variation in trust of various governments or institutions is a result of differences in the way the citizens view social phenomena for which some of the responsibility is attributed to the authorities such as economic growth, inflation, stability of government, insecurity, unemployment rate, etc., (Craen \& Skogan, 2014). In other words, what constitutes good performance of government or a government institution includes (but not limited to) economic growth, stability in government, employment, safety, etc. while inflation, unemployment, crime, insecurity, and other negative socio-economic conditions constitute bad performance.

Relating performance theory to policing, the theory states that, the citizen will have high level of trust in the police that render services that meet their expectations, i.e., police with good performance will have the trust of the community they serve (Boateng, 2017). The question, therefore, is what kind of service do the citizens expect the police to render or what constitutes good performance? Since the citizens expect an environment that is crime free, police performance could, therefore, be measured by the following (but not limited to) variables; fear, safety, and order, that is the ability of the citizens to feel safe in their neighborhood; ethics and value, that is the ability of the police to maintain high ethical standards and be respectful in dealing with citizens or police-citizen interaction ; Legitimacy, the ability of the police to interact with people who request their services, people who are detained and promotes satisfaction and confidence in the people; and, crime and victimization, the ability to reduce crime and victimization rate through police visibility and by responding promptly to crime (Davis, Ortiz, Euler, \& Kuykendall, 2015; Wu, Sun, \& Smith, 2011; Skogan, 2009; Dukes, Portillos, \& Miles, 2009; Priest \& Carter, 1999). Put it differently, performance theory suggests that, in an environment that crime rate is high, high level of insecurity, unethical behavior of police, poor police-citizen interactions, and other negative security related issues; the citizens will have less trust in such police (Craen \& Skogan, 2014).

Police scholars have examined the effects of the above-mentioned police performance variables on citizens' trust but with conflicting results from modest to no effects. However, while some of these variables have been given much attention, others have received little attention (Boateng, 2017). For example, effects of victimization, crime, fear of crime, and police visibility on public trust have been examined by scholars with significant results (Kumar, 2017; Pare, 2014; Sindall \& Sturgis, 2013; Lindstrom, 2013; Kaariainen, 2008). In a study on fear of crime and trust carried out by Kumar (2017), it was found out that victims of property crimes had greater level of satisfaction and trust in the police than victims of violent crime when the crimes are solved. According to the study. victims of violent crime only have the possibility of benefit of retribution through punishment of the offender, and do not have the advantage of any restitution, while victims of property crimes have the benefits of restitution in 
addition to the punishment that will be given to the offender.

Kaariainen (2008) examined the relationship between insecurity and trust in the police, concluded that insecurity in one's neighborhood lowers trust in police. Also, Pare (2014) in his study that provides the first empirical test of the relationship between indicators of police performance and homicide rates in cross-national perspective, concluded that lower homicide rate is strongly associated with police performance, simply put, low rate of violate crime will enhance public trust in the police and high rate will lower the trust. Furthermore, Reynolds, Semukhina, and Demidov (2008), indicated that fear of crime affects the citizens' perception of the police; the higher the fear of crime, the less confident the citizens will be about their police. Adorjan and Lee (2016) study carried out in Hong Kong indicated that public satisfaction and trust in the police is in part based on perception of police effectiveness to combat crime, that the technical competence and dependability of the police as crime fighters generally play a positive role in enhancing public trust. However, the study indicated that the people still care more about police civilities/respectfulness and fairness (ethics and value) when dealing with members of the public than effectiveness narrowly defined in terms of crime fighting. Simply put civilities/respectfulness and police fairness are more significantly related to enhancing public trust in the police than crime fighting variable. Hinds (2009) concluded in her work on Public satisfaction with police: the influence of general attitudes and police-citizen encounters that, the most significant predictors of people's satisfaction with police were the general attitude measures of police legitimacy, police performance, that is, people's perceptions about how well police do their job, and procedural justice.

In summary, performance theory of policing suggests that trust in the police is based on the degree to which citizens are bothered by crime, disorder, feelings of insecurity, corruption, incivility, unethical behaviors of the police, and the injudicious use of authority by the police. The current study, therefore, aims to examine how easily accessible the police are to the public to determine their performance and if this has any effects on the public trust in the police, an area which has not been examined by police scholars in Nigeria.

\subsection{Empirical Background}

Nigerian police just like the police in every part of the world are an inevitable institution without which the society cannot function and develop (Ojo, 2014). The society needs the police to run and function smoothly and in the same manner, the police need the society (public support) to successfully perform their core duty of fighting crime and criminals. Thus, there should be cordial relationship between the police and the public. However, the situation is not so in Nigeria (Ojo, 2014; Madaki \& Kurfi, 2013), it is characterized by distrust and uncooperative attitude from the members of the public towards the police (Ajibade, 2011; Ojo, 2014). According to Chukwuma, Obe, Otu, Mu'azu, Effah-Chukwuma, Osori, Itodo, and Nwagu (2012) one of the root causes of this situation is the colonial nature of the Nigerian Police and the inability of the post-independent Nigerian leaders to change Nigerian Police from the colonial occupation force into a service-oriented and accountable public institution.

Nigerian Police as a product of colonialism emerged over a century ago following the annexation of Lagos in 1861. The British administrators who were in charge of the affairs of the Lagos colony put together a group of about 30 Hausa-speaking ex-slaves from Sierra Leone 
known as Consular Guard (Tamuno, 1970), not to serve the public but rather to protect the interest of the colonial master and their cronies through subjugation and repression of the indigenous people (Onyeozili, 2005). This group of 30 Hausa-speaking ex-slaves known as the Consular Guard was aliens to the indigenous people; the group did not speak the language or understand the culture, and yet carried out the role of "maintaining of law and order" in the colony by mere force, and as a result established in the minds of the people distrust and hatred for the organization (Ahire, 1991, 1993). Not surprising, therefore, that even after independence, the Nigerian Police continued to play the role of protecting the Nigerian hegemonies, subjugating and repressing the masses; the situation got worse during the military regimes in terms of human rights abuse, abuse of power and authority, corruption, criminal conduct, and the use of excessive force (Otu \& Aro, 2014).

Very few empirical studies in Nigeria have examined public perception of the Nigerian Police. Perhaps one of the exceptions is the research carried out by John (2017) where public perception of police activities in a semi urban area, Okada in Edo State, Nigeria was carried out. The study adopted descriptive cross-sectional survey design. Study population consisted of members of resident community. A sample of 194 respondents was used and this size was statistically determined using Cochran's formula. Data were collected at quantitative and qualitative levels. The outcome of the research indicated that, Police services in bad manner or otherwise corrupts activities of Police services, most respondents believed that Police personnel abused human rights and are fond of demanding gratification from the citizens. Again, 55.6\% of the respondents said Police collaborated with criminals to aid and abet crime in their society. Finding showed that $71.1 \%$ of the respondents believed that Police officers extort money from travelers on the high way patrols. Similarly, 52.6\% of the respondents said there is a nonchalant attitude among Police officers in times of distress calls. The implication of the finding is that police service delivery is fraught with many practices that undermine public trust and lack luster attitude to cooperate in community policing. John (2017), findings echoes part of the results of a previous empirical work on public confidence in the Nigerian Police by Ayodele and Aderinto (2014). The results of their study showed that $69.7 \%$ of respondents had no confidence in the police

In addition to the above two studies, several related areas of literature can be drawn to further explore the Nigerian Police and the public in general and Nigeria police accessibility in particular. Study demonstrated that contact with the police also shape the people's attitude towards the police (Rosenbaum, Schuck, Costello, Hawkins, \& Ring, 2005). Research has further demonstrated that citizen initiated contacts with police (examples, reporting a crime, request for assistance) have stronger influence in shaping people's opinion and attitude towards the police than the police initiated contact such as traffic stops for driving offenses approaching members of the public as witnesses (Skogan, 2005). However, irrespective of who initiated the contact, police helpfulness, fairness, politeness, speedy response and attentiveness to what people had to say are most significant in shaping people's perception and ultimately trust in the police (Skogan, 2005, 2006; Adorjan \& Lee, 2016).

Police accessibility in Nigeria, that is, the ability of the Nigerian police to be reached easily by the public when reporting a crime, asking for assistance, requesting for their services, or making distress call, is a mirage. Nigerian police are corrupt, unfriendly, money extorters, 
intimidators, abusers of authority and power (Hills, 2008; Madaki \& Kurfi, 2013; Ojo, 2014; Akinlabi, 2017; Igbo, 2017), thus reaching out to them before, during, and after crime is a difficult process (Ordue \& Nnam, 2017).

To foreshadow the later results, I found that police accessibility has a significant impact on public trust of the Nigerian police. The remainder of this article is set as follow; first, the data, key measures, and analysis are described, then the empirical results are presented, and then finally, the discussion and conclusion.

\section{Method}

\subsection{Data Source and Sample}

This study aimed to understand the impact, if any, of police accessibility on public trust in Nigerian police. To test this, the study used data from the quality of democracy and governance in Nigeria by Afrobarometer, data Round 6, 2015-2016. Afrobarometer used the 2006 population and housing census of the Federal Republic of Nigeria to draw their sample size of 2,400 , and this sample consisted of citizens of Nigeria who are 18 years old and above. The sample design was made to reflect every group within the country including the rural and urban dwellers; it was nationally representative, random, clustered, stratified, and multi-stage area probability sample. The country was divided into strata from where the Primary Sampling Unit (PSU) was drawn. And to get their PSU, Afrobarometer used probability proportionate to population size (PPPS) and 8 households per PSU drawn. The first point of the household was randomly selected, then was followed by walk pattern using 5/10 interval. The final selection which involved the selection of an individual respondent from each household was gender quota filled by alternating interviews between men and women respondents of appropriate gender listed, after which household member draws a numbered card to select individuals. The contact rate according to Afrobarometer was $89.9 \%$ and the response rate was $69.5 \%$.

\subsection{Measures}

\subsubsection{Dependent Variable}

The dependent variable for this study is trust in police. To measure this, Afrobarometer asked the 2400 respondent this question, "How much do you trust each of the following, or haven't you heard enough about them to say: The Police?" The values are: $0-3,9,98$, and -1 . For $0=$ Not at all, 1 = Just a little, $2=$ Somewhat, $3=$ A lot, $9=$ Don't know/Haven't heard enough, 98 $=$ Refused to answer, and $-1=$ Missing.

\subsubsection{Independent Variables}

The independent variable for this study is police accessibility. To get the police accessibility variable from the Afrobarometer raw data, 4 variables were merged, these variables are: police station in the PSU/EA, Police in the PSU/EA, difficulty to obtain help from the police, and pay bribe to avoid problem with police. The first 2 variables were chosen because the numbers of police officers in Nigeria (about 350,000 police officers) compared to her population of about 186 million is approximately 187 officers to 100,000 people, about 1 officer to 531 citizens (INTERPOL, 2017). This is far below the United Nation recommendation of an approximate median of 300 police officers per 100,000 inhabitants (Twelfth United Nations Congress on Crime Prevention and Criminal Justice, p. 19). Thus, it is the view of the author that the higher the number of the police officers, the easier it will be for the public to reach them for help. 


\section{Ml Macrothink}

The last 2 variables were chosen because studies have shown that to get help from police in Nigeria is a difficult task, and that Nigerian police are corrupt (Hills, 2008; Madaki \& Kurfi, 2013; Ojo, 2014; Akinlabi, 2017; Igbo, 2017). It is therefore the opinion of the author that citizens will avoid such police organization that is corrupt and turn to alternative means even when they are in dire need of such police organization's help.

For these 4 variables, respondents were asked if there is a police station in the primary sampling unit/enumeration area or within easy walking distance, and if they see any policemen in the primary sampling unit/enumeration area. The two had the same response categories: "No, Yes, Can't determine." Respondents were further asked if they requested assistance from the police in the past 12 months, and if yes, how difficult was it to obtain help from the police. The response categories for this are: "Very easy, Easy, Difficult, Very difficult, No contact, Don't know, Refused to answer." Also, they were asked how often they have to pay a bribe in order to get the needed assistance or avoid problem with the police, with the following response categories: Never, Once or twice, A few times, Often, No contact, Don't know, Refused to answer (Afrobarometer, 2016).

Table 1. Descriptive statistics of participants in the study

\begin{tabular}{ll}
\hline Study Variable & Mean (SD)\% \\
\hline Age (min. = 18 and max. =56-101) & $31.78(10.60)$ \\
Male & 50.2 \\
Employed & 52.6 \\
Education & \\
Senior high school or below & 63.8 \\
Senior high school and above & 27.3 \\
Location & \\
Urban & 43.6 \\
Rural & 56.4 \\
\hline
\end{tabular}

The demographic distribution of the study respondents is presented in Table 1 . The respondents are evenly split based on gender, $50.2 \%$ male and $49.8 \%$ female, with an average age of 31 years $(\mathrm{SD}=10.60)$. The youngest person was 18 years old. Furthermore, about $52.6 \%$ were employed. Moreover, about $63 \%$ of the respondents claimed they have senior high school or below and about $27 \%$ claimed they have senior high school and above. About $43.6 \%$ of the respondents dwelled in the rural areas while about $56.4 \%$ dwelled in the urban areas. Regarding trust in police, about $46 \%$ claimed they do not at all have no trust in police, $31 \%$ claimed they have just a little trust in police, $15 \%$ claimed their trust in police is just somewhat, and about $6 \%$ claimed they have a lot of trust in police, and 1\% claimed they didn't know (Afrobarometer, 2016). 


\section{Presentation of Analysis}

The primary objective of this study was to test the effects of police accessibility on trust in Nigeria Police. To achieve this objective, several analyses were conducted, specifically; descriptive statistics, correlation, and multiple regression analysis were utilized. The correlation was used as a bivariate technique to test the relationship between the independent (predictor) and the dependent variables and to determine if the relationships were significant or not. The multiple regression analysis was also utilized to further understand the relationship between the predictor and the dependent variables and the relative importance of the predictor on dependent variable.

Table 2. Public trust in Nigerian police

\begin{tabular}{llll}
\hline & Frequency & Percentage & Cummulative percentage \\
\hline Not at all & 1097 & 45.7 & 45.7 \\
Just a little & 744 & 31.0 & 76.7 \\
Somewhat & 380 & 15.8 & 92.5 \\
A lot & 150 & 6.3 & 98.8 \\
Don't know/ Haven't heard enough & 29 & 1.2 & 100.0 \\
Total & 2400 & 100.0 & \\
\hline
\end{tabular}

Table 2 shows the description of respondents who answered to the survey. Out of 2400 respondents, 45.7 percent of respondents do not have trust in the Nigerian police, 31 percent of respondents have just a little bit of trust for the Nigerian police, 15.8 percent of respondents have a somewhat trust in the Nigerian police while 6.3 percent of respondents have a lot of trust in the Nigerian police. 1.2 percent of respondents have not heard enough to decide if they can trust the Nigerian police or not.

\subsection{Correlation}

Table 3 below shows the individual correlation between trust in police and police accessibility variables (i.e. presence of police station, presence of policemen and vehicles, difficulty in obtaining assistance from police and paying of bribe to avoid problems with police). Trust in police was correlated with presence of police station, presence of policemen and vehicles and paying of bribe to avoid problems with police at a significant level of $p<0.05$ while trust in police and difficulty to obtain help from the police was correlated at $\mathrm{p}<0.01$

The Pearson correlation between trust in police and presence of police station on the PSU/EA is 0.029 and the significant level is $p=0.016<0.05$. This shows that there is a very weak significant positive relationship between trust in police and the presence of police stations in PSU/EA. This implies that as the more the presence of police stations in PSU/EA, the more trust the people have in the Nigerian police force.

The Pearson correlation between trust in police and presence of policemen and police vehicles in the PSU/EA is 0.036 and the significant level is $p=0.008<0.05$. This shows that there is a 
very weak significant positive relationship between trust in police and the presence of policemen and vehicles in PSU/EA. This implies that as the more the presence of policemen and police vehicles in PSU/EA, the more trust the people have in the Nigerian police force.

Also, the Pearson correlation between trust in police and difficulty in obtaining assistance from police is -0.064 and the significant level is $p=0.002<0.01$. This shows that there is a very weak significant negative relationship between trust in police and the difficulty in obtaining assistance from police. This implies that as the more the difficulty in obtaining assistance from police is, the less trust the people have in the Nigerian police force.

Lastly, the Pearson correlation between trust in police and paying of bribe to avoid problems with police is -0.045 and the significant level is $p=0.027<0.05$. This shows that there is a very weak significant negative relationship between trust in police and paying of bribe to avoid problems with police. This implies that as the more the public pay bribe to police to avoid problems, the less trust the people have in the Nigerian police force. In addition, from table 7, it shows that difficulty in obtaining assistance from the police has the highest relationship with public trust in police followed by paying of bribe to avoid problems with police, followed by the presence of policemen and police vehicles in PSU/EA and lastly, the presence of police stations in PSU/EA.

Table 3. Correlation between trust in police and presence of police station, presence of policemen and vehicles, difficulty in obtaining assistance from police and paying of bribe to avoid problems with police

\begin{tabular}{|c|c|c|c|c|c|}
\hline & & $\begin{array}{l}\text { Police station } \\
\text { in the } \\
\text { PSU/EA }\end{array}$ & $\begin{array}{l}\text { Police in the } \\
\text { PSU/EA }\end{array}$ & $\begin{array}{l}\text { Difficulty in } \\
\text { obtaining help } \\
\text { from the police }\end{array}$ & $\begin{array}{l}\text { Pay bribe to } \\
\text { avoid problem } \\
\text { with police }\end{array}$ \\
\hline \multirow[t]{3}{*}{$\begin{array}{l}\text { Trust in } \\
\text { police }\end{array}$} & $\begin{array}{l}\text { Pearson } \\
\text { correlation }\end{array}$ & .029 & .036 & $-.064 *$ & -.045 \\
\hline & Sig. (2-tailed) & .016 & .008 & .002 & .027 \\
\hline & $\mathrm{N}$ & 2400 & 2400 & 2400 & 2400 \\
\hline
\end{tabular}

*Correlation is significant at the 0.01 level (2-tailed).

\subsection{Multiple Regression}

The effect of police accessibility (i.e. presence of police station in PSU/EA, the presence of policemen and police vehicles in the PSU/EA, difficulty in obtaining assistance from police and paying of bribe to avoid problems with police) on the public trust in the Nigerian police was tested using multiple regression analysis. From Table 4 which shows the regression summary, $\mathrm{R}$ value $=0.081$ represents the simple correlation which indicates a low degree of correlation between public trust in the Nigerian police force and the four variables tested. From the same regression summary - Table 4 , $\mathrm{R}$ Square value $=0.005$ shows public trust in the Nigerian police force is affected by $0.5 \%$ of the police accessibility variables (i.e. presence of police stations, presence of policemen and vehicles, difficulty in obtaining assistance from police and paying of bribe to avoid problems with police). 
Also, Table 4 under the change statistics, shows that the regression model significantly predicts public trust in the Nigerian Police force in the PSU/EA as $p=0.003<0.05$. In other words, all the independent variables analyzed have significant effect on public trust in the Nigerian Police force in the PSU/EA.

In addition to the information provided on table 4, the standard error of the estimate $=1.27496$ and this is a litmus test indicating the validity of the data analysed. Hence, the result of this analysis can be trusted.

Lastly, Table 5 shows that public trust in the Nigerian police force can be predicted significantly by the four variables of police accessibility (i.e. presence of police stations, presence of policemen and vehicles, difficulty in obtaining assistance from police and paying of bribe to avoid problems with police) by the formula below;

$\mathrm{Y}=1.140+0.023 \mathrm{X} 1+0.039 \mathrm{X} 2-0.081 \mathrm{X} 3+0.036 \mathrm{X} 4$

Where $\mathrm{Y}=$ Public trust in the Nigerian police,

$\mathrm{X} 1=$ Presence of Police station in the PSU/EA

$\mathrm{X} 2=$ Presence of Policemen and Police Vehicles in the PSU/EA

$\mathrm{X} 3$ = Difficulty to obtain help from the police, and

$\mathrm{X} 4$ = Payment of bribe to avoid problem with the police

Table 4. Regression Summary

\begin{tabular}{|c|c|c|c|c|c|c|c|c|c|}
\hline \multirow[t]{4}{*}{ Model } & \multirow[t]{4}{*}{$\mathrm{R}$} & \multirow{4}{*}{$\begin{array}{l}\mathrm{R} \\
\text { Square }\end{array}$} & \multirow{4}{*}{$\begin{array}{l}\text { Adjusted } \\
\text { R Square }\end{array}$} & \multirow{4}{*}{$\begin{array}{l}\text { Std. Error of } \\
\text { the Estimate }\end{array}$} & \multicolumn{2}{|c|}{ Change Statistics } & \multirow{4}{*}{ df1 } & \multirow{4}{*}{$\mathrm{df} 2$} & \multirow{4}{*}{$\begin{array}{l}\text { Sig. F } \\
\text { Change }\end{array}$} \\
\hline & & & & & $\mathrm{R}$ & $\mathrm{F}$ & & & \\
\hline & & & & & Square & Change & & & \\
\hline & & & & & Change & & & & \\
\hline & $.081^{\mathrm{a}}$ & .007 & .005 & 1.27496 & .007 & 3.936 & 4 & $2395^{\mathrm{a}}$ & .003 \\
\hline
\end{tabular}

Table 5. Regression coefficients

\begin{tabular}{|c|c|c|c|c|c|}
\hline \multirow[t]{2}{*}{ Model } & \multicolumn{2}{|c|}{$\begin{array}{l}\text { Unstandardized } \\
\text { Coefficients }\end{array}$} & \multirow{3}{*}{$\begin{array}{l}\text { Standardized } \\
\text { Coefficients } \\
\text { Beta }\end{array}$} & $\mathrm{t}$ & \multirow[t]{2}{*}{ Sig. } \\
\hline & $\mathrm{B}$ & Std. Error & & & \\
\hline (Constant) & 1.140 & .084 & & 13.609 & .000 \\
\hline $\begin{array}{l}\text { Police station in the } \\
\text { PSU/EA. }\end{array}$ & .023 & .027 & .019 & .833 & .041 \\
\hline Police in the PSU/EA. & .039 & .042 & .021 & .925 & .036 \\
\hline $\begin{array}{l}\text { Difficulty to obtain } \\
\text { help from the police. }\end{array}$ & -.081 & .029 & -.144 & -2.759 & .006 \\
\hline $\begin{array}{l}\text { Pay bribe to avoid } \\
\text { problem with police. }\end{array}$ & .036 & .021 & .089 & 1.699 & .009 \\
\hline
\end{tabular}




\section{Discussion and Conclusion}

This objective of this study was to test police accessibility effects on public trust of Nigerian Police. The study used R6 data collected through survey in Nigeria by Afrobarometer from 2014 to 2015. Specifically, 4 variables from the raw data were used to capture police accessibility, these variables are: presence of police station, presence of policemen and vehicles, difficulty in obtaining assistance from police, and paying bribe to avoid problems with the police. The finding generally revealed that police accessibility is significantly related to trust in Nigerian Police, that is, the easier the police could be reached by the public, the more trust the public will have in the police.

Specifically, each of the 4 variables used to capture police accessibility in this study lends support to findings from other previous studies. The first 2 variables used, which are, the presence of police station, and the presence of policemen and vehicles (police visibility and numbers) in the primary sampling unit (PSU) both have significant positive relationships with public trust in police, that is, the more the presence of police stations, policemen and police vehicles, the more the trust in the police. This finding buttress Sindall \& Sturgis (2013) conclusion that visibility and numbers of police officers have significant and positive effect on public confidence in the police; however, this result comes with a caveat, which is, the presence of police stations, policemen and vehicles cannot solely be taken for accessibility, other factors have to come into play which include among others the readiness and willingness of the officers to carry out their functions and other forms of public services to the community when called for assistance by members of the public without any form of venality.

The other findings that deserve emphasis are results from the third and fourth variables that were used to capture police accessibility; the third variable used revealed a negative relationship between trust in Nigerian Police and difficulty in obtaining assistance from the police, that is, the more the difficulty in obtaining assistance from the police, the less trust in the police. This assistance does not solely mean to respond to crime but also include other forms of assistance like request for assistance by crime victims, request for location of missing person and recovery of lost property, bail of suspects, and other social obligations required of the police. This buttress what Goldsmith (2005) identified as trust-diminishing behaviour by the police, viz: neglect and indifference. Both neglect and indifference are forms of unresponsiveness, indicative of a lack of dedication; by neglect, it means when the police lack a tradition of public service to the community at large. And indifference suggests a failure to take the concerns of persons seriously, a lack of attention and of sympathy for their concerns, which among others include rudeness and incivility (Goldsmith, 2005).

When asked in the past 12 months have you requested assistance from the police? And how easy or difficult was it to obtain assistance they needed from the police? Majority of the respondents $(56.5 \%)$ indicated no contact with the police, $17.5 \%$ responded very difficult and only $13.6 \%$ responded easy. Although, the police and the citizens are always in daily contacts, however, reaching out to the police for help, most especially by those in low socio-economic status, prior to, during, and after the commitment of a crime is always problematic. Aside this, requesting for bail of suspects, needing assistance by crime victims, and reporting of crime are also difficult. Thus, most Nigerians would rather avoid the police and use some other alternative means to get needed assistance than to request such from the police. 
This supports the view of Ladapo (2011) that, "the average Nigerian citizen views the police with awe ... there is the ever-present fear of being accused of perpetrating the offence one reports to the police, reprisal attacks from the person the report is made against, due to the potential leakage of information by the police to the suspects. It is not also uncommon for the police to require the person reporting a crime to fund the subsequent investigation and make endless return visits to the police station for one reason or the other, leading to an enormous loss of man-hours (p. 81). It is not surprising therefore that the International body rates Nigeria Police the worst globally (Punch 12, 2017).

Finally, the findings revealed a negative relationship between trust in Nigerian Police and paying bribe to avoid problems with the police, that is, the more the public pay bribe to police to avoid problems, the less trust the people have in the Nigerian police force. The public expect their police to carry out their constitutional duties without any form of venality which is common with the Nigerian police officers (Akinlabi, 2017; Goldsmith, 2005; John, 2017; Ojo, 2014; Ordu \& Nnam, 2017).

There is a saying in some quarters in Nigeria that, "you can't have police as your friend or as your enemy; either way, there is a price to pay". Thus in conclusion, reaching out to the Nigerian police to request assistance, report of crime, volunteer information that may help in solving crime, and to be a witness, is problematic. The citizens know this and would rather avoid them if they can and seek alternative means. This consequently affectcs negatively the citizens'trust in the police.

The present study is not without limitations, and these must be acknowledged. Firstly, this study used data from Afrobarometer survey thereby made it impossible for some follow up questions that may further deepen our understanding of police accessibility in Nigeria. Secondly, most of the respondents used in the survey (57\%) stated they had no contact with the police in the past 12 months preceding the survey, thus there is need for a more qualitative study to be carried out among individuals who have had contact with the police

However, despite these limitations, findings from the present study have significant implication for policing in Nigeria. Policing / fighting crime in today's world is no longer a solo effort of the police organization, it is a joint effort of both the public and the police, members of the public need the police for protection, and the police needs the public cooperation and support in order to be successful in protecting the public. Therefore, the Nigeria police needs to do more in making itself accessible to the public if it wants to be successful in its war on crime.

\section{References}

Adorjan, M., \& Lee, M. (2016). Public assessments of the police and policing in Hong Kong. Australian \& New Zealand Journal of Criminology, 1-19.

Ahire P. T. (1991). Imperial Policing: The Emergence and Role of the Police in Colonial Nigeria, 1860-1960. Milton Keynes: Open University Press.

Ahire P. T. (1993). Native authority police in Nigeria: End of an era. In: Policing Nigeria: Past, Present and Future. Lagos: Malthouse Press.

Ajibada, D. (2011). Crime prevention and control in Nigeria: A study of Ogun State police command. African Journal of Law and Criminology, 1, 131-139. 
Akinlabi, O. M. (2017). Do the police really protect and serve the public? Police deviance and public cynicism towards the law in Nigeria. Criminology \& Criminal Justice, 17(2), 158-174. https://doi.org/10.1177/1748895816659906

Alemika, E. E. O., \& Chukwuma, I. O. (2003). Analysis of police and role of policing as a barrier to change or driver of change in Nigeria. Lagos: Clean Foundation.

Alemika, E., \& Chukwuma, I. (2000). Police-Community Violence in Nigeria. Lagos: CLEEN/NHRC.

Ansari, S., \& He, N. (2015). Convergence revisited: A multi-definition, multi-method analysis of the UCR and the NCVS crime series (1973-2008). Justice Quarterly, 32, 1-31. https://doi.org/10.1080/07418825.2012.718355

Ayodele, J. O., \& Aderinto, A. A. (2014). Public Confidence in the Police and Crime Reporting Practices of Victims in Lagos, Nigeria: A Mixed Methods Study. International Journal of Criminal Justice Sciences (IJCJS), 9(1), 46-63.

Boateng, F. D. (2017). Institutional trust and performance: A study of the police in Ghana. Australian \& New Zealand Journal of Criminology, 1-19. https://doi.org/10.1177/0004865817712335

Brown, B., \& Benedict, W. R. (2002). Perceptions of the police: Past findings, methodological issues, conceptual issues and policy implications. Policing: An International Journal of Police Strategies \& Management, 25(3), 543-580. https://doi.org/10.1108/13639510210437032

Bouckaert, G., Van de Walle, S., Maddens, B., \& Kampen, J. K. (2002). Identity vs. Performance: An Overview of Theories Explaining Trust in Government. Public Management Institute. Katholieke Universiteit Leuven.

Cao, L., \& Hou, C. (2001). A comparison of confidence in the police in China and in the United $\begin{array}{llllr}\text { States. Journal of } & \text { Criminal }\end{array}$ https://doi.org/10.1016/S0047-2352(00)00084-2

Chukwuma, I., Obe, A., Otu, S.E., Mu'azu, A., Effah-Chukwuma, J., Osori, A., Itodo, S., \& Nwagu, C. (2012). Civil society panel on police reform in Nigeria Final report.

Craen, M. V., \& Skogan, W. G., (2014) Differences and similarities in the explanation of ethnic minority groups' trust in the police. European Journal of Criminology, 1-24.

Davis, R. C, Ortiz, C. W., Euler, S., \& Kuykendall, L. (2015). Revisting "Measuring What Matters:" Developing a Suite of Standardized Performance Measures for Policing. Police Quarterly, 18(4), 469-495. https://doi.org/10.1177/1098611115598990

Dukes, R., Portillos, E., \& Miles, M. (2009). Models of satisfaction with police service. Policing, 32, 297-318. https://doi.org/10.1108/13639510910958190

Einstein, S., \& Amir, M. (2003). Police Corruption: Paradigms, Models and Concepts: Challenges for Developing Countries. Huntsville, TX: Office of International Criminal Justice.

Goldsmith, A. (2005). Police Reform and the Problem of Trust. Theoretical Criminology, 9(4), 443-470. https://doi.org/10.1177/1362480605057727

Hills, A. (2008). The Dialectic of Police Reform in Nigeria. Journal of Modern African Studies, 46(2). https://doi.org/10.1017/S0022278X08003200

Hinds, L. (2009). Public satisfaction with police: the influence of general attitudes and 
police-citizen encounters. International Journal of Police Science and Management, 11(1), 54-66. https://doi.org/10.1350/ijps.2009.11.1.109

Igbo, E. U. M. (2017). The Use and Abuse of Police Powers and Extra Judiciary Killings in Nigeria. African Journal of Criminology and Justice Studies: AJCJS, 10(1), 83-99.

Ikuomola, A. D. (2011). Intelligence information and policing in Nigeria: Issues and way forward. Journal of International Social Research, 4, 474-484.

Interpol (2017) "Nigeria". https://www.interpol.int/Member-countries/Africa/Nigeria Retrieved 30 November 2017.

Jackson, B., Hough, K., Stares, W., Fitzgerald, Yo., \& Gelov. (2011). Developing European indicators of trust in justice. European Journal of Criminology, 8(4), 267-285. https://doi.org/10.1177/1477370811411458

John, M. D. (2017). Public Perception of Police Activities in Okada, Edo State Nigeria. Covenant Journal of Business \& Social Sciences (CJBSS), 8(1), 29-42.

Kaariainen, J. (2008). Why do the Finns trust the police? Journal of Scandinavian Studies in Criminology and Crime Prevention, 141-159. https://doi.org/10.1080/14043850802450294

Karstedt, S., \& LaFree, G. (2006). Democracy, crime, and justice. The Annals of the American Academy of Political and Social Science, 605, 6-23. https://doi.org/10.1177/0002716206288230

Kasali, M. A. (2012). Analyzing the evolution of private security guards and their limitations to security management in Nigeria. African Journal of Criminology and Justice Studies, 5, 32-48.

Kasali, M. A. \&Odetola, R. G. (2016). Alternative Approach to Policing in Nigeria: Analyzing the Need to Redefine Community Policing in Tackling the Nation's Security Challenges. African Journal of Criminology and Justice Studies: AJCJS, 9(1), 98-115.

Kumar, T. K V. (2017). Mediating influence of crime type on victim satisfaction with police services: A comparative analysis across victims of property crimes and violent crimes in India. International Review of Victimology, 1-23.

Ladapo, O. A. (2011). Effective Investigations, A Pivot To Efficient Criminal Justice Administration: Challenges In Nigeria. African Journal of Criminology and Justice Studies: AJCJS, $5(1 \& 2)$, 79-94.

Lambert, E., Wu, Y., Elechi, O., \& Jiang, S. (2012). Correlates of support for community police partnerships in policing among Nigerian and US college students: An exploratory study. International Criminal Justice Review, 22, 276-296. https://doi.org/10.1177/1057567712456873

Lindstrom, P. (2013). More Police-Less Crime? The Relationship Between Police Levels and Residential Burglary in Sweden. The Police Journal, 86(4), 321-339. https://doi.org/10.1350/pojo.2013.86.4.633

Madaki, M., \& Kurfi M. H. (2013). Toward Enhancing Police-Community Relations in Nigeria: Problems and Prospects. Journal of Sociological Research, 4(2), 125-134. https://doi.org/10.5296/jsr.v4i2.3972

Ojekunle, U. A. (2014). Contributing Factors to Police Homicide in Nigeria. Police Journal: 
Theory, Practice and Principles, 87, 41-48. https://doi.org/10.1350/pojo.2014.87.1.651

Ojo, M. O. D. (2014). The Nigeria police and the search for integrity in the midst of diverse challenges: an effective police management approach. International Journal of Police Science and Management, 16(2), 87-100. https://doi.org/10.1350/ijps.2014.16.2.330

Onyeozili, E. C. (2005). Obstacles to Effective Policing in Nigeria. African Journal of Criminology and Justice Studies, 1(1), 32-54.

Ordu, G. E., \& Nnam, M. U. (2017). Community Policing in Nigeria: A Critical Analysis of Current Developments. International Journal of Criminal Justice Sciences, 12(1), 83-97.

Otu, N. (2012). Balanced Policing Model in the Republic of Nigeria. The Police Journal, 85, 235-253. https://doi.org/10.1350/pojo.2012.85.3.588

Otu, S. E., \& Aro, G. C. (2014). Dealing with professionalism and acquiring and managing legitimacy in a constitutional democratic policing in Nigeria: Where goes the procedural justice approach? Journal of the Institute of Justice and International Studies, 13, 149-170.

Pare, Paul-Philippe. (2014). Indicators of Police Performance and Their Relationships With Homicide Rates Across 77 Nations. International Criminal Justice Review, 24(3), 254-270. https://doi.org/10.1177/1057567714548453

Priest, T., \& Carter, D. (1999). Evaluations of police performance in an African American sample. Journal of Criminal Justice, 27, 457-465. https://doi.org/10.1016/S0047-2352(99)00016-1

Reynolds, K. M., Semukhina, O. B., \& Demidov, N. N. (2008). A longitudinal analysis of public satisfaction with the police in the volgograd region of Russia 1998-2005. International Criminal Justice Review, 18, 158-189. https://doi.org/10.1177/1057567708318484

Rosenbaum, D. P., Schuck, A. M., Costello, S. K., Hawkins, D. F., \& Ring, M. K. (2005). Attitudes toward the police: The effects of direct and vicarious experience. Police Quarterly, 8(3), 343-365. https://doi.org/10.1177/1098611104271085

Schulhofer, S. J., Tyler, T. R., \& Huq, A. Z. (2011). American policing at a crossroads:Unsustainable policies and the procedural justice alternative. Journal of Criminal Law and Criminology, 10, 335.

Sindall, K., \& Sturgis, P. (2013). Austerity policing: Is visibility more important than absolute numbers in determining public confidence in the police? European Journal of Criminology 10(2), 137-153. https://doi.org/10.1177/1477370812461237

Skogan, W. G. (2005). Citizen satisfaction with police services: Individual and $\begin{array}{lllll}\text { contextualeffects. } & \text { Police } & \text { Studies } & \text { Journal, } & 7,\end{array}$ https://doi.org/10.1111/j.1541-0072.1978.tb01795.x

Skogan, W. G. (2006). Asymmetry in the impact of encounters with the police. Policing and Society, 16(2), 99-126. https://doi.org/10.1080/10439460600662098

Skogan,W. G. (2009). Concern about crime and confidence in the police: Reassurance or accountability? Police Quarterly, 12, 301-318. https://doi.org/10.1177/1098611109339893

Skogan, W., \& Antunes, G. (1979). Information, Apprehension and Deterrence: Exploring the Limits of Police Productivity. Journal of Criminal Justice, 7, 217-241. https://doi.org/10.1016/0047-2352(79)90040-0 
Tamuno, T. N. (1970). The Police in Modern Nigeria, 1861-1965: Origins, Development and Role. Ibadan: Ibadan University Press.

The Punch. (2017). International body rates Nigeria Police worst globally. http://punchng.com/international-body-rates-nigeria-police-worst-globally/

Wua, Y., Poteyeva, M., \& Sun, Y. I. (2012). Trust in police: A comparison of China and Taiwan. International Journal of Comparative and Applied Criminal Justice, 36(3), 189-210. https://doi.org/10.1080/01924036.2012.699794

Wu, Y., \& Sun, I. (2009). Citizen Trust in Police. The Case of China. Police Quarterly, 12(2), 170-191. https://doi.org/10.1177/1098611108330228

Wu, Y., Sun, I., \& Smith, B. (2011). Race, immigration, and policing: Chinese immigrants' satisfaction with police. Justice Quarterly, 28, 745-774. https://doi.org/10.1080/07418825.2010.535009

\section{Copyright Disclaimer}

Copyright for this article is retained by the author(s), with first publication rights granted to the journal.

This is an open-access article distributed under the terms and conditions of the Creative Commons Attribution license (http://creativecommons.org/licenses/by/3.0/). 